\title{
Qualitative and Quantitative Analysis of the Inorganic Materials Changes with Time in the Stages of the Wastewater Treatment Plant
}

\author{
Falah Bani Hani $^{*}$, Mohammad Abdallah Qasaimeh ${ }^{1}$, Ahmad Qasaimeh ${ }^{2}$ \\ ${ }^{1}$ Department of Chemical Engineering, Al-Huson University College, Al-Balqa' Applied University, Salt, Jordan \\ ${ }^{2}$ Civil Engineering Department, Jerash University, Jerash, Jordan \\ Email: *dr.falahf@yahoo.com
}

Received May 20, 2012; revised June 17, 2012; accepted June 30, 2012

\begin{abstract}
Due to the importance of the inorganic materials removal from wastewater, experimental and analytical study to the concentration change with time of these materials became essential. In this work, experimental analyses were performed to investigate the concentration changes of inorganic compounds during stages of activated sludge wastewater treatment plants at different sites in Jordan. The aim of this research is to examine the performance of the plants in treating pollutants and inorganic materials, and verify the quantitative and qualitative changes with time. Samples from the treatment stages were monthly taken and analyzed in the laboratory along a period of one year. The concentration changes of the inorganic solids in wastewater passing through treatment stages and aeration tank were recorded. Results show that the conventional treatment of the wastewater within different conditions in the year is not effective to decrease the concentrations of the inorganic compounds. Based on these results, we recommend adding tertiary advanced treatment unit in order to get acceptable water quality allowable to be reused for different purposes.
\end{abstract}

Keywords: Water Treatment; Inorganic Compounds; Operational Stages; Concentration Changes

\section{Introduction}

Wastewater contains various substances of soluble and suspended materials. The soluble substances are very ting, while the suspended ones are relatively bigger. According to their nature, they both can be organic and inorganic substances [1]. This classification is very important to unit design and unit operation in wastewater treatment. Continuous changes in these substances and in their ratios take place as a result of the physical and environmental effects, changing the conditions of water in the wells $[2,3]$. When wastewater enters a plant, it passes different stages of various and successive conditions mainly, anoxic, re-oxygenation, and re-non-oxygenation.

The anoxic conditions usually happen in detention well, where wastes are collected and drained in a consistent way into the flowing wells. In this stage some changes are expected occurring such as a simple breakup to the organic substances; dissolution to the suspended ones; a decrease in oxygen and changes in salts. These changes may occur in the equalization tank with no aeration conditions. In other hand, the re-oxygenation conditions usually happen to the dumped materials when they

${ }^{*}$ Corresponding author. enter the aeration tank, where organic substances are oxidized in a prominent change in treatment plants. In renon-oxygenation conditions, the case is the secondary precipitation tank, where no aeration, the dissolved oxygen in water is decreased, and some changes happen to the various compounds in wastewater [2,3]. Further important changes happen, the most important of which, is nitrification of the nitrogen organic compounds and ammonia into nitrates $[3,4]$.

In all these changes, researcher interest becomes concentrated on the organic substances as the main pollutant along with other pollutants can be inorganic. The change in the organic substances and their content at different treatment stages may some times be associated to the organic substances. In other cases, these changes are associated with the changes in the other inorganic substances under the influence of the surrounding conditions. These inorganic substances (solids) are very dangerous to the environment mainly when thrown to the water sources and dams. The organic substances (solids) are a reason for the appearance of problems, which most often related to the re-cycling of the treated water for different purposes [2,5] mainly in agriculture, where salts become the main obstacle in this use. However, the treated water 
can be used in some industrial operations such as washing, sweeping, and cooling in outside towers and pools. Existence of salts also causes further problems that acquire a need to urgent checking to these inorganic substances. Studying the function of the treatment plants and the identification of the inorganic substances with their contents in the treated water become now important and essential for the different uses of the treated water. The concentration of the inorganic impurities and their change with organic substances changes in treated water can now be linked and become an important part in wastewater treatment field [6].

For the huge and harmful effects of the inorganic substances in water, and the necessity of their removal, many countries established a number of treatment plants to solve their environmental problems and save their water resources. In research field, many workers in literature gave their attention to find out economical and environmental methods to remove these inorganic materials. Furthermore, the phosphate compounds, and particularly the polyphosphates, were proposed as good removals to the inorganic wastes [7]. Chemical oxidants such as ozone, chlorine, chlorine dioxide, and chloramines, besides their disinfection role, were also used since a number of organic and inorganic compounds can go reactions with these oxidants [8-16]. One case of oxidants is chlorine, which was reported capable to undergo reactions with numerous inorganic and organic micro pollutants [17]. The $\mathrm{HOCl}$, the major reactive chlorine species during chlorination processes, was also reported capable to react with organic and inorganic pollutants [17].

In water treatment using phosphate compounds to remove inorganic materials, the polyphosphates were recommended because their solutions usually exhibit a colloidal disperse and wetting powers on the inorganic or metal particles. On heating, these polyphosphates will react with the particles through oxoacidity reaction [7]. One cheap industrial salt commercially used is sodium polyphosphate, known as Graham or hexametaphosphate salt. Comparatively to other uses of these phosphates, their usage in waste treatment - particularly in inorganic wastes - has become a minor compared to other uses; one is the treatment of nuclear wastes [7].

In water treatment using chemical oxidants, the ozone, chlorine, chlorine dioxide, and chloramines are reported used for various purposes: disinfection of microorganisms, oxidation in taste and odor control, and elimination of the micro pollutants [8-16]. Under certain circumstances, these oxidants could induce the formation of the harmful by-products due to their highly reactivity with water matrix components and micro pollutants [1824]. These oxidants were generally low cost; one was chlorine, the one used in water disinfection in pre and post treatments. Despite its low activity on microorga- nisms in biofilms, chlorine was reported to lead to a significant removal of the majority of the planktonic bacteria $[25,26]$.

In inorganic materials removal, chlorine was reported to react with numerous inorganic and organic micro pollutants [17]. Chlorine showed low reactivity for certain compounds, where small modifications were needed under typical water treatment conditions [17]. For most micro pollutants, $\mathrm{HOCl}$ was reported the major reactive chlorine species during chlorination processes [17]. In the case of inorganic compounds, fast reactions of ammonia, halides $\left(\mathrm{Br}^{-}\right.$and $\left.\mathrm{I}^{-}\right), \mathrm{SO}_{3}^{2-}, \mathrm{CN}^{-}, \mathrm{NO}_{2}^{-}, \mathrm{As}$ (III) and $\mathrm{Fe}$ (II) with $\mathrm{HOCl}$ were reported. In other hand, low chlorine reaction rates were reported with $\mathrm{Mn}$ (II) in homogeneous systems. Chlorine reactivity usually results from an initial electrophilic attack of $\mathrm{HOCl}$ on inorganic compounds. In the case of organic compounds, secondorder rate constants for chlorination varied over 10 orders of magnitude [17]. Oxidation, addition, and electrophilic substitution reactions were reported possible with organic compounds. From a kinetic view, only electrophilic attack was significant. The reactivity of chlorine, limited to particular sites: amines, reduced sulfur moieties, activated aromatic systems, was observed during chlorination processes. Small modifications in compound's structure were also expected for primary attack [17]. Linear structure-activity relationships can be used to make predictions and estimations of the functional groups reactivity. For more, comparison of chlorine reactivity with that of ozone towards the aromatic compounds showed a good correlation with chlorine rate constants of about four orders of magnitude smaller than those for ozone [17].

Further important effect of the inorganic materials in water is the industrial scale. The inorganic elements exhibited major effects where numbers of works were performed to control mineral precipitation and scaling in industrial waters [27-30]. Several reviews compared the performance of natural and synthetic materials as scale control agents to control the precipitation of several mineral such as calcium carbonate, calcium sulfate, calcium phosphate, calcium phosphonate, calcium fluoride, and barium sulfate [31-34]. Process variables and water chemistry also influenced the performance of polymers as calcium phosphate precipitation inhibitors and iron oxide dispersants $[35,36]$.

In Jordan, the small developing country of limited water resources and with population increase, pollution problems generated from inorganic and organic materials are getting more serious. The population increased rapidly from 0.58 millions in 1950 to more than 6.5 millions in 2006 [37]. This high growth along with the rapid economical development is accompanied with an increase in the water demand, while the limited water re- 
sources are decreasing. Jordan's water resources are, on per capita basis, among the lowest in the world. There are twenty three municipal treatment plants usually cover the major cities and towns, and serve about $56 \%$ of the population. The total inflow to these plants is about $234,914 \mathrm{~m}^{3} / \mathrm{d}$; part of which $\left(224,175 \mathrm{~m}^{3} / \mathrm{d}\right)$ inflows into Asamra wastewater treatment plant (ASTP) [38]. Jordanian standards for reclaimed wastewater [39] try to regulate both water reuse and environmental discharges.

Now referred to what reported on the danger of the inorganic substances, and based on the lack of Jordan to the water resources and the inorganic treatments, the change in the concentration of the inorganic compounds at different stages in water treatment plant took our attention and work. Based on this view, we proposed our objectives; one was to find out the relations that link the inorganic impurities (the nitrates, phosphates, sulfurs, and chlorides) at different treatment stages. The second was to get a clearer view on the treatment plant ability to remove these substances. The third was to identify the concentration change effects of these substances that function in wastewater before and after treatment. The forth was to get a guidance to the methods that can better enhance the treatment plant in removing the inorganic along with organic substances.

\section{Materials and Methods}

The samples were taken from a chosen two locally and acceptable wastewater treatment plants in northern Jordan. These plants worked with the system of continuous activated aeration sludge and with an organic loading in the range of $0.02-0.3 \mathrm{~kg} \mathrm{BOD} / \mathrm{kg}$ MLVSS. The out put treated water from these plants is mostly consumed in secondary uses and applications such as irrigation, covering the needs of Irbid city and the villages around.

These samples were taken from successive sites in the chosen plants, or mainly from places at different stages as follows: one place was from the influent water entering the plant at the entrance of the station, or locations before entering the aeration tank; the second was from water being-treated in the aeration tank; and the third was from the effluent treated water released out of the plant.

To emphasis results and avoid confusion, analyses were concentrated on qualitative indicators in this work. These indicators were $\mathrm{NO}_{3}^{-}, \mathrm{PO}_{4}^{3-}, \mathrm{Cl}^{-}$, alkalinity, $\mathrm{PH}$, $\mathrm{EC}$, chemical oxygen demand (COD), and suspended solids. Laboratory tests with consistent specifications [40] and monthly samplings were taken and continued for one year with short break only for technical reasons.

\section{Discussion}

\subsection{The Nitrates}

Nitrates are one of the important and main compounds in the field of wastewater treatment. They have positive and negative importance. Nitrogen and its compounds have their importance in the biological treatment of organic materials in processes of activated sludge. They further have importance in other biological treatment, since they are part of the biological tissue structure of the micro organisms working in organic treatment (the most important treatment) with tissue ratios of 1,5 , and 100 for $\mathrm{C}$, $\mathrm{N}$, and $\mathrm{P}$ elements. It is well known that $\mathrm{C}$ represents the concentration of organic substances (solids) or carbon, $\mathrm{N}$ represents nitrogen, and $\mathrm{P}$ represents phosphoric compounds. Therefore, the condition to achieve a biological treatment and form biological tissue is the existence of nitrogen storage that becomes a part of the biological structure $[38,41]$. Such existence in treated water is indicated by the negative nitrates, which play an important role in nutrition enrichment and made our attention and concern to study nitrate content in out-flowing water. Result of this work (Figure 1) shows that nitrates in most months enter site (I) with a very low concentration that does not mean a non-existence of nitrogen compounds. The reason of such low concentration is the existence of other nitrogen compounds such as organic nitrogen, ammonia, urea and more $[5,6,42]$. Occurrence of a simple non-aeration conditions cause a change of nitrates into nitrogen and ammonia, decreasing the nitrate concentration in the entering materials. The increase in nitrate concentration in aeration tank is noticed in most months for sites I, and II, which is attributed to the existence of the oxygen and occurrence of nitrification processes that change ammonia and organic nitrogen into nitrates $[41,42]$. In other hand, in thrown away materials, a simple fall in nitrates is noticed in most months as a result of the occurrence of simple anoxic conditions in the precipitation tank, which lead to the change of nitrates into $\mathrm{N}_{2}$ by de-nitrification bacteria. Existence of nitrates in aeration tank shows a successful biological efficiency, which is not obtained in the case of nitrates nonexistence.

\subsection{The Phosphates}

Phosphates compounds are important in the field of wastewater treatment. It is part of the structure of the biological tissue of the micro-organisms considered as the main element. Its absence causes weakness and malfunction of the biological treatment, making it important in treatment as nitrates. It is undesirable in the resulting water from treatment for its negative effect on lakes and water surfaces. Referring to our results of the examined sites (Figure 2), fluctuation of phosphates concentration is noticed in the three stages of treatment in all sites and in most months, and phosphate concentration decreases in water in treatment stages. Such result agrees with what 


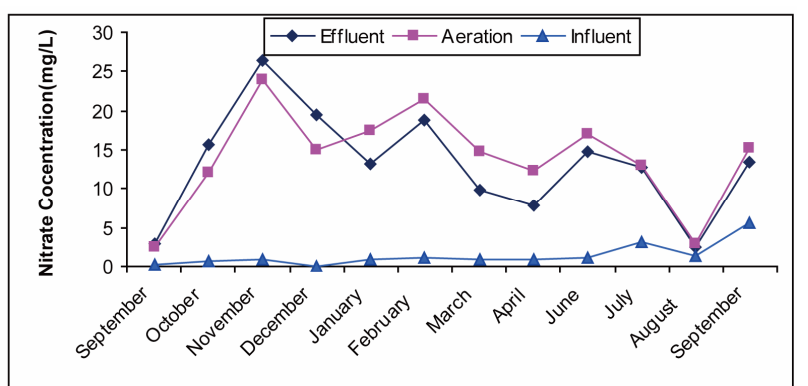

(a)

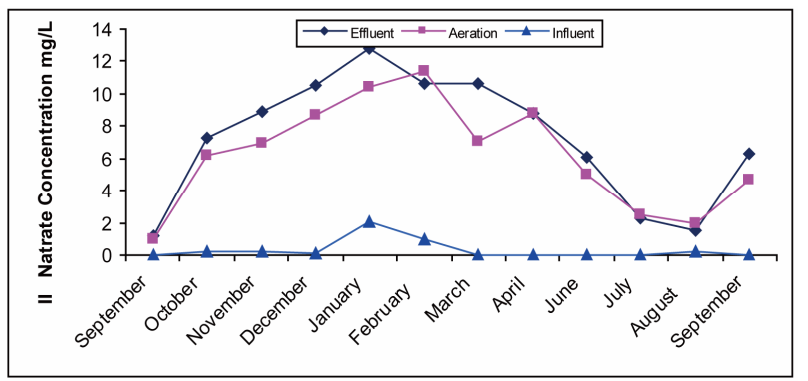

(b)

Figure 1. (a) Change of the concentration of nitrate in the Site I; (b) Change of the concentration of nitrate in the Site II.

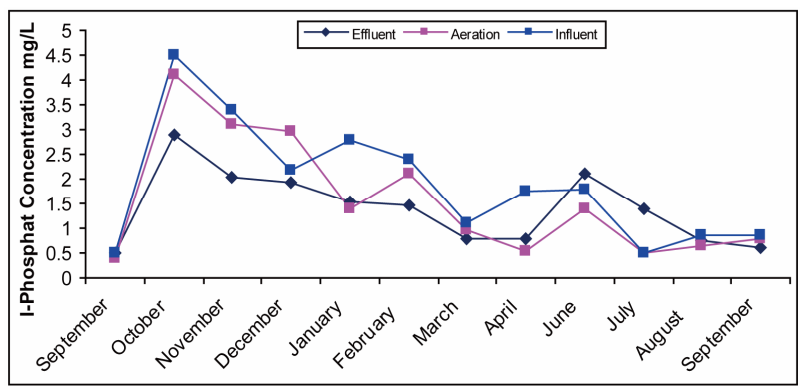

(a)

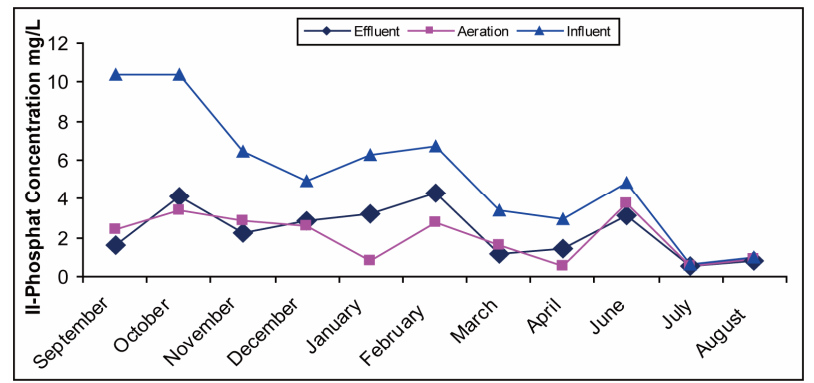

(b)

Figure 2. (a) Change of the concentration of Phosphate in the Site I; (b) Change of the concentration of Phosphate in the Site II.

stated in other work [4] and is attributed to its consumption in building up the biological tissue. It has been noticed in some station working with activated sludge treatment that phosphate removal is much bigger than the amount used in building the cellular tissue (1-5-100).

\subsection{The Sulfurs}

Sulfur compounds usually exist in the flow water and increase in the thrown away materials as a result of the domestic uses $(15-20 \mathrm{mg} / \mathrm{L})$. Our analytical results are shown in Figure 3. Through observation, it is noticed that sulfurs begin with a certain concentration of materials under treatment (Influent). Simple decrease in concentration happens is attributed to the change of part of sulfurs into the sulfide in non-aeration or anoxic conditions in detention well and equalization tank. Simple part of sulfurs is consumed in building up cellular tissue as sulfur is one of the main elements takes a part in cellular tissue structure along with carbon, nitrogen and phosphor.

\subsection{The Chlorides}

Chlorides compounds are very important in wastewater treatment field through their impact on treatment uses and quality of water mainly in agricultural and industrial purposes. The increase in the concentration of chloride happens as a result of domestic use with estimated range of $20-50 \mathrm{mg} / \mathrm{L}$ [4]. Sometimes, the big increase occurs as a result of throwing away washing water containing ion exchanges used in purifying boilers' water as noticed in some months indicated in Figure 4. It is noticed that

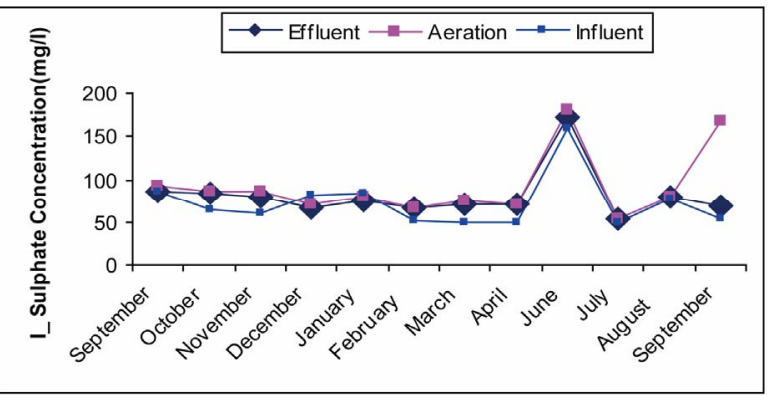

(a)

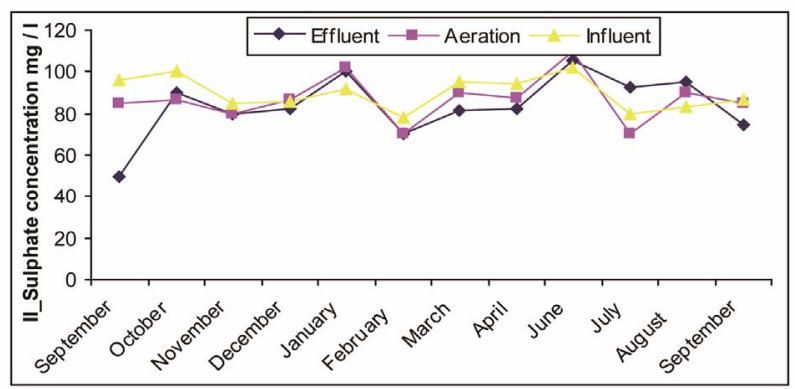

(b)

Figure 3. (a) Change of the concentration of sulphate in the Site I; (b) Change of the concentration of sulphate in the Site II. 


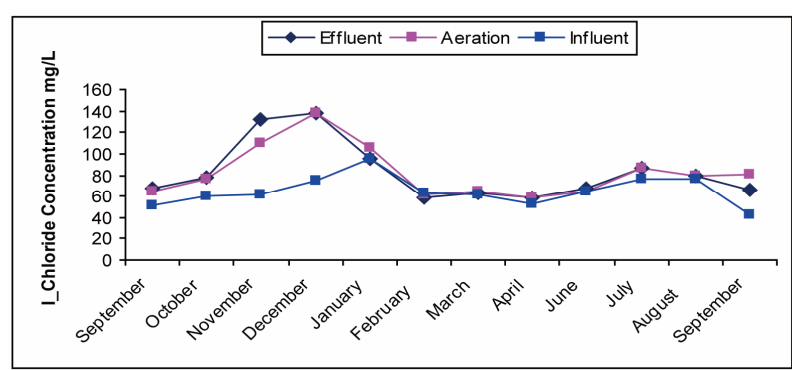

(a)

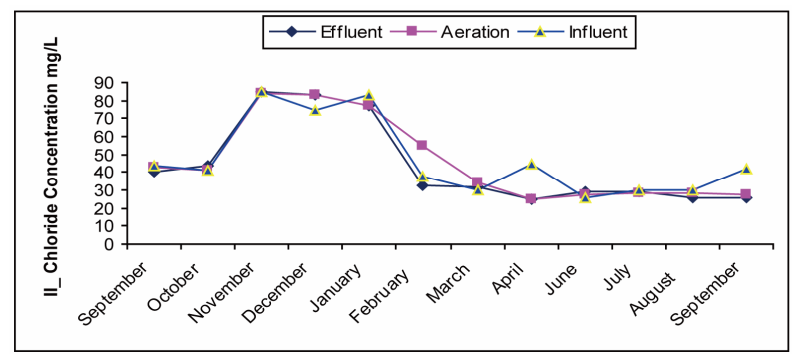

(b)

Figure 4. (a) Change of the Concentration of Chloride in the Site I; (b) Change of the Concentration of Chloride in the Site II.

there is no clear change in chloride concentration in treated water during the treatment stages except for the change resulting from the variety of the doses arriving and entering. This is governed by the hydraulic characteristics of treatment tanks during day where no consumption and removal of chlorides during the biological treatment. It is noticed that existence of concentration increase of chlorides in upper layers of water more than normal values can be attributed to its exposure to the throwing away wastewater close to the site.

\subsection{The Alkalinity}

Alkalinity refers to the existence of inorganic compounds as mostly existed in thrown away materials mostly as hydroxides, carbons, calcium bicarbonates, magnesium, sodium, and ammonia. The most common are calcium bicarbonates and magnesium as was measured in this research. The importance of alkalinity becomes evident when there is a chemical treatment. The alkalinity of the wastewater comes from several sources mainly are flow water, intermixing and exchange of underground water, and domestic use which adds about (50 - $100 \mathrm{mg} / \mathrm{L})$ as bicarbonates $[1,4,43]$. In this study, a significant decrease in alkalinity level during treatment is noticed. The cause of this decrease is due to the consumption (take up) of alkalinity occurred in aeration tank during nitrification process, which needed $7.1 \mathrm{gm}$ of alkalinity per $1 \mathrm{gm}$ of ammonia change into nitrates. Such effect is clearly shown in Figure 5. Low increase in some months is noticed mostly for hydraulic reasons; the measured sample

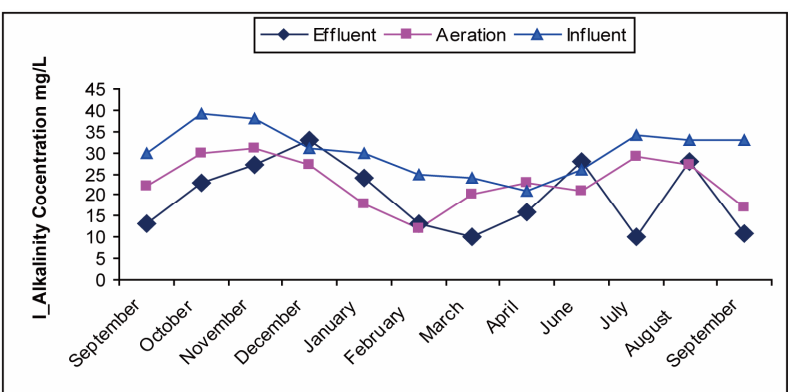

(a)

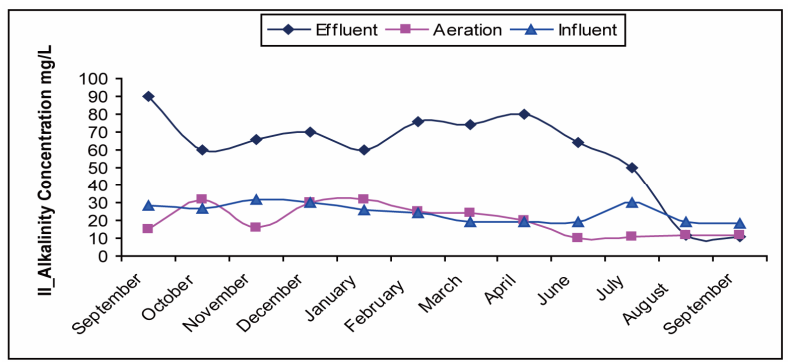

(b)

Figure 5. (a) Change of the concentration of alkalinity in the Site I; (b) Change of the concentration of alkalinity in the Site II.

takes more hydraulic time than that of the designed time of the plant. This affects the characteristic of the samples taken in one day, because the taken samples are of composite sample kind and sometimes they are of the grab sample kind. This means that the product is a completion of the previous day with previous characteristic of the sample taking day.

\subsection{The Electrical Conductivity}

Electrical Conductivity is one of the measures followed at wastewater treatment plants, and neglected with existence of salts. There was a low level conductivity of treated water in the aeration tank that could be due to the change of ions in to insoluble precipitates. Significant changes in electrical conductivity values in first and second sites are noticed in Figure 6.

Other Indicators, the total insolvency represented as calcium and magnesium is one of these indicators. There was no constant state of insolvency change, whereas the reason behind the fluctuation of insolvency concentration results from water under treatment. It is known that biological unit does not affect insolvency concentration in treated water [44]. The Hydrogenic Allas Measure is also one of the important indictors used to follow up the performance of different tanks in wastewater treatment plants; its increase means the success of biological areolation unit (activated sludge tank) performance. This performance increase is noticed in the stations under this study. 


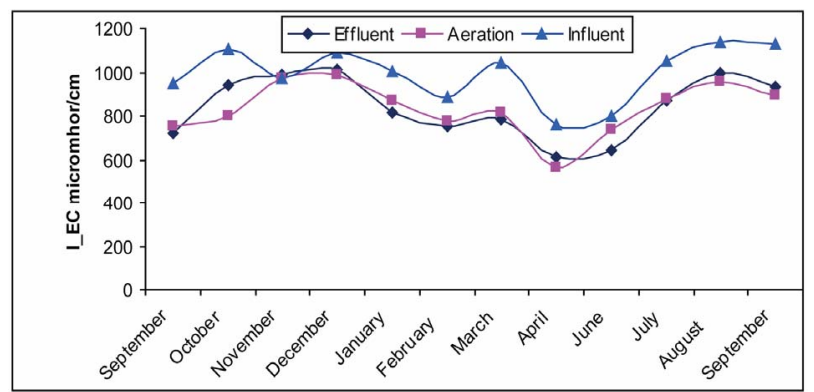

(a)

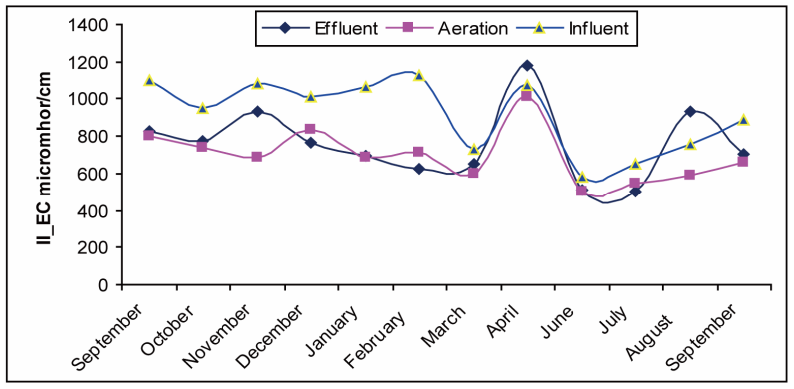

(b)

Figure 6. (a) The change of EC in the Site I; (b) The change of EC in the Site II.

\section{Conclusion}

In this work, the changes in the inorganic compounds concentration in the biological waste water treatment stages are found to be an indicator to its failure to remove the inorganic materials to the accepted levels. Most conventional wastewater treatment plants work to remove the organic compounds with no consideration to the inorganic materials. For a purpose of treatment amendment to the acceptable level for different municipal uses, we need advanced treatment units such as nitrification-denitrification to remove nitrogen, alum-lime addition to remove phosphorus, ion exchange technique to remove soluble salts, and filtration through activated carbon to remove color-causing inorganics. Uses of water without these treatment methods will leave water harmful to the industry and agricultural applications in long term.

\section{Acknowledgements}

The authors would like to thank the Scientific Research Deanship in Al-Huson University College, Al-Balqa Applied University for their support.

\section{REFERENCES}

[1] Metcalf and Eddy, "Wastewater Engineering, Treatment, Disposal and Reuse," McGraw-Hill Inc., New York, 1991.

[2] R. Alabaide, "The Changing of Concentration Inorganic Compound in Deferent Stage of Treatment Plant," Journal of Pure \& Applied Science, Vol. 2, No. 2, 2010, pp.
53-61.

[3] B. Y. Ammary and J. A. Radaideh, "Simultaneous Nitrification and Denitrification in an Oxidation Ditch Plant," Chemical and Biochemical Engineering, Vol. 9, No. 2, 2005, pp. 207-212.

[4] G. A. Ekama and M. C. Wentzel, "Modeling Inorganic Material in Activated Sludge Systems," Water SA, Vol. 30, No. 2, 2004, pp. 153-174. doi:10.4314/wsa.v30i2.5060

[5] M. Von Sperling, "Solids Management for the Control of Extended Aeration Systems," Water SA, Vol. 20, No. 1, 1994, pp. 49-60.

[6] K. D. Kerri, "Operation of Wastewater Treatment Plants," 5th Edition, California State University, Sacramento, 2001.

[7] P. Vast, V. Andris, M. A. U. Martines, J. P. Aufferedic, M. Poulain and Y. Messaddeq, "Treatment and Destruction of Inorganic Fibers Wastes Like Asbestos by Sodium Polyphosphate," Phosphorus Research Bulletin, Vol. 15 2004, pp. 68-82.

[8] J. C. Hoff and E. E. Geldreich, "Comparison of the Biocidal Efficiency of Alternative Disinfectants," Journal of American Water Works Association, Vol. 73, No. 1, 1981, pp. 40-44, 1981

[9] R. L. Wolfe, N. R. Ward and B. H. Olson, "Inorganic Chloramines as Water Disinfectants: A Review," Journal of American Water Works Association, Vol. 76, No. 5, 1984, pp. 74-88.

[10] J. C. Morris, "Aqueous Chlorine in Treatment of Water Supplies," In: N. M. Ram, E. J. Calabrese, R. F. Christmas, Eds., Organic Carcinogens in Drinking Water: Detection, Treatment and Risk Assessment, Wiley, New York, 1986, pp. 33-54.

[11] G. A. Burlingame, J. J. Muldowney and R. E. Maddrey, "Cucumber Flavour in Philadelphia's Drinking Water," Journal of American Water Works Association, Vol. 84, No. 4, 1992, pp. 92-97.

[12] J. Hoigne, "Chemistry of Aqueous Ozone and Transformation of Pollutants by Ozonation and Advances Oxidation Processes," In: J. Hubrec, Ed., The Handbook of Environmental Chemistry, Springer-Verlag, Berlin, 1998.

[13] C. Gottschalk, J. A. Libra and A. Saupe, "Ozonation of Water and Waste Water: A Practical Guide to Understand Ozone and Its Application," Wiley-VCH, Weinheim, 2000.

[14] U. von Gunten, "Ozonation of Drinking Water: Part I. Oxidation Kinetics and Product Formation," Water Research, Vol. 37, No. 7, 2003, pp. 1443-1467. doi:10.1016/S0043-1354(02)00457-8

[15] B. Legube, "Ozonation By-Products," The Handbook of Environmental Chemistry, Vol. 5, 2003, pp. 95-116.

[16] A. Bruchet and J. P. Duguet, "Role of Oxidants and Disinfectants on the Removal Masking and Generation of Tastes and Odours," Water Science and Technology, Vol. 49, No. 9, 2004, pp. 297-306.

[17] M. Debordea and U. von Guntena, "Reactions of Chlorine with Inorganic and Organic Compounds during Water Treatment-Kinetics and Mechanisms: A Critical Review," Water Research, Vol. 42, No. 1-2, 2008, pp. 13-51. doi:10.1016/j.watres.2007.07.025 
[18] B. Cancho, F. Ventura, M. Galceran, A. Diaz and S. Ricart, "Determination, Synthesis and Survey of Iodinated Trihalomethanes in Water Treatment Processes," Water Research, Vol. 34, No. 13, 2000, pp. 3380-3390. doi:10.1016/S0043-1354(00)00079-8

[19] Y. Bichsel and U. von Gunten, "Formation of Iodo-Trihalomethanes during Disinfection and Oxidation of Iodide-Containing Waters," Environmental Science \& Technology, Vol. 34, No. 13, 2000, pp. 2784-2791. doi:10.1021/es 9914590

[20] J. E. Simmons, S. D. Richardson, T. F. Speth, R. J. Miltner, G. Rice, K. M. Schenck, E. S. Hunter III and L. K. Teuschler, "Development of a Research Strategy for Integrated Technology-Based Toxicological and Chemical Evaluation of Complex Mixtures of Drinking Water Disinfection Byproducts," Environmental Health Perspectives, Vol. 110, Suppl. 6, 2002, pp. 1013-1024. doi:10.1289/ehp.02110s61013

[21] S. D. Richardson, A. D. Thruston, C. Rav-Acha, L. Groisman, I. Popilevsky, O. Juraev, V. Glezer, A. B. McKague, M. J. Plewa and E. D. Wagner, "Tribromopyrrole, Brominated Acids and Other Disinfection Byproducts Produced by Disinfection of Drinking Water Rich in Bromide," Environmental Science \& Technology, Vol. 37, No. 17, 2003, pp. 3782-3793. doi:10.1021/es030339w

[22] M. J. Plewa, E. D. Wagner, S. D. Richardson, A. D., Thruston, Y. T. Woo and A. B. Mckague, "Chemical and Biological Characterization of Newly Discovered Iodoacid Drinking Water Disinfection Byproducts," Environmental Science \& Technology, Vol. 38, No. 18, 2004, pp. 4713-4722. doi:10.1021/es049971v

[23] S. D. Richardson, "New Disinfection By-Product Issues: Emerging DBPs and Alternative Routes of Exposure," Global NEST Journal, Vol. 7, No. 1, 2005, pp. 43-60.

[24] S. W. Krasner, H. S. Weinberg, S. D. Richardson, S. J. Pastor, R. Chinn, M. J. Sclimenti and G. D. Onstad, A. D. Thruston, "Occurrence of a New Generation of Disinfection Byproducts," Environmental Science \& Technology, Vol. 40, No. 23, 2006, pp. 7175-7185. doi:10.1021/es060353j

[25] M. W. Le Chevallier, C. D. Cawthon and R. G. Lee, "Factors Promoting Survival of Bacteria in Chlorinated Water Supplies," Applied and Environmental Microbiology, Vol. 54, No. 3, 1988, pp. 649-954.

[26] F. Y. Bois, T. Fahmy, J. C. Block and D. Gatel, "Dynamic Modeling of Bacteria in a Pilot Drinking-Water Distribution System," Water Research, Vol. 31, No. 12, 1997, pp. 3146-3156. doi:10.1016/S0043-1354(97)00178-4

[27] Z. Amjad, "Mineral Scale Formation and Inhibition," Plenum Publishing Corporation, New York, 1995.

[28] L. A. Perez and D. Zidovec, "Mineral Scale Formation and
Inhibition," Plenum Publishing Corporation, New York, 1995.

[29] J. Hoots and G. A. Crucil, "Role of Polymers in the Mechanisms and Performance of Alkaline Cooling Water Programs," Paper No. 13, Corrosion/86, NACE International, Houston, 1986.

[30] Z. Amjad, "Controlling Metal Ion Fouling in Industrial Water Systems," UltraPure Water, 2000, UP170431.

[31] Z. Amjad, Ed., "Calcium Phosphates in Biological and Industrial Systems," Kluwer Academic, Boston, 1997.

[32] Z. Amjad, "Water Soluble Polymers: Solution Properties and Applications," Plenum Publishing, New York, 1998.

[33] Z. Amjad, "Inhibition of Barium Sulfate Precipitation: Effect of Additives, Solution $\mathrm{pH}$, and Supersaturation," Water Treatment, Vol. 9, 1994, pp. 47-56.

[34] W. F. Masler and Z. Amjad, "Advances in the Control of Calcium Phosphonate with a Novel Polymeric Inhibitor," Paper No. 11, Corrosion/89, NACE International, Houston, 1988.

[35] Z. Amjad, J. Pugh, J. F. Zibrida and R. W. Zuhl, "Performance of Polymers in Industrial Water Systems: The Influence of Process Variables," Materials Performance, Vol. 36, No. 1, 1997, pp. 32-38.

[36] Z. Amjad, "Factors to Consider in Selecting a Dispersant for Industrial Water Systems," UltraPure Water, Vol. 16, No. 7, 1999, pp. 17-24.

[37] Statistical Department, "Population of Jordan," Annual Report, Jordan, 2006.

[38] S. Malkawi, "Current Reclaimed Water Use in Jordan: Strategies, Policies and Standards," The Second Water Reuse Conference, Amman, 6-9 June 2005n.

[39] Jordanian Standards 1995, "Jordanian Standards for Water Reuse JS893/1995,” Amman, 1995.

[40] APHA, AWWA, ASCE, "Standard Methods for Water and Wastewater Examination and Tests," APHA, AWWA, ASCE, New York, 2000.

[41] W. W. Eckenfelder Jr., "Biological Treatment of Wastewater," McGraw-Hill Inc., New York, 1998.

[42] W. Gujer and D. Jenkins, "A Nitrification Model of the Contact Stabilization Process," Water Research, Vol. 9, No. 5-6, 1975, pp. 561-566. doi:10.1016/0043-1354(75)90082-2

[43] W. W. Eckenfelder Jr., "Industrial Water Pollution Control," McGraw-Hill Inc., New York, 1989.

[44] R. Jamal, Z. Kamel and Q. Omar, "Modern Wastewater Treatment Technologies for Better Treatment and Water Reuse," International Conference on Water Conservation in Arid Regions, Jeddah, 12-14 October 2009. 